\title{
Hamsa
}

Journal of Judaic and Islamic Studies

1 | 2014

Islamic and Jewish Studies

\section{From the history of Muslims to Muslims in History: Some critical notes on "Arab-Islamic Studies" in Portugal}

Maria Filomena Lopes de Barros

\section{(2) OpenEdition}

Journals

Electronic version

URL: https://journals.openedition.org/hamsa/876

DOI: $10.4000 /$ hamsa.876

ISSN: 2183-2633

Publisher

CIDEHUS - Centro Interdisciplinar de História Culturas e Sociedades da Universidade de Évora

\section{Electronic reference}

Maria Filomena Lopes de Barros, "From the history of Muslims to Muslims in History: Some critical notes on "Arab-Islamic Studies" in Portugal", Hamsa [Online], 1 | 2014, Online since 31 December 2014, connection on 13 May 2021. URL: http://journals.openedition.org/hamsa/876 ; DOI: https://doi.org/ 10.4000/hamsa.876

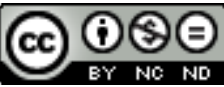

Hamsa est mise à disposition selon les termes de la Licence Creative Commons Attribution - Pas d'Utilisation Commerciale - Pas de Modification 4.0 International. 


\title{
From the history of Muslims to Muslims in History: Some critical notes on "Arab-Islamic Studies" in Portugal
}

\author{
Maria Filomena Lopes de Barros \\ Universidade de Évora - CIDEHUS \\ mfbarros@uevora.pt
}

\begin{abstract}
Resumo:
Os estudos árabe-islâmicos em Portugal apresentam particularismos a nível do panorama europeu. A comparação com a realidade espanhola evidencia as diferenças estruturais que, desde o séc. XVIII, revelam uma descontinuada aposta na língua árabe, que nunca evoluiu para um quadro filológico autónomo. De resto, a história dos muçulmanos, enquanto parte integrante do passado português, apenas se começa a reinscrever nos discursos das ciências sociais e humanas após a revolução de Abril de 1974, numa mudança de paradigma ainda não totalmente conseguida.
\end{abstract}

Palavras-chave: Portugal, Espanha, estudos árabe-islâmicos, Islão, muçulmanos

\section{Abstract:}

The Arabic-Islamic studies in Portugal reveal some particularities within the European context. The comparison with Spain shows the structural differences that, from its origin in the $18^{\text {th }}$ century, reveal a discontinuity investment in the Arabic language, which never evolved into an independent philological framework. Moreover, the history of Muslims, as an integral part of the Portuguese past only begins to re-inscribe in the discourse of social and human sciences after the 1974 Revolution, in a paradigm shift not yet fully achieved.

Key words: Portugal, Spain, Arabic-Islamic studies, Islam, Muslims

Muslims have suffered from a lack of visibility in Portuguese history, due to the ideological colonialism discourse, corrected only partially after the revolution of April $25^{\text {th }}$ 1974. Let us stress: only partially. Essentialist discourse on Islam, even in the academic milieu, constitutes a new concealment, projecting and reinforcing the representation conveyed by the media and by common sense ${ }^{1}$. This reflection is multiplied by infinite mirrors intensifying and reproducing the same picture - which other scientific discourses are unable to unmake - and which inevitably will have a negative impact on the foundations of a hopefully multicultural future.

The perspectives on which studies on Muslims in Portugal became crystallised, centred on History but not limited to it, inform this text. It's very title indicates a critical stance on the

\footnotetext{
${ }^{1}$ Consider, in this context, the text by AbdoolKarim Vakil, "Pensar o Islão: Questões coloniais, interrogações pós-coloniais", Revista Crítica de Ciências Sociais 69 (2004), pp. 17-52.
} 
concept of "Arab Islamic studies". In effect, as explained by Maria Cardeira da Silva in a foundational article on this subject, the first problem arising from this kind of analysis has to do with "the fluidity of frontiers among fields of study", assuming "an essentialist, multidisciplinary approach of the Orientalist kind", but in reality being no more than "a relatively dense, though not very wide, network of researchers of different fields and backgrounds", made up along the way and relying on personal acquaintance ${ }^{2}$. Things haven't changed much since 2005, when the article was published, although that network has grown in density and complexity, both in and out of academia.

This fluidity in frontiers, mentioned by the author quoted above, points to something inescapable: the very inexistence of a consistent body of Arabists in Portugal. Although here and there we can spot some moments when knowledge in this field was reproduced, through a chain of masters and disciples, such moments are dated and above all discontinuous. The same process is repeated from the $18^{\text {th }}$ to the $21^{\text {st }}$ centuries, giving rise in present times to an academic panorama in which Arabic language disciplines abound, but no corresponding philology course exists - or has ever existed. The Arabic language, which in the beginnings of Orientalism was regarded as an ancila theologiae ${ }^{3}$, remains in Portugal a purely auxiliary instrument, for the benefit of other scientific areas. On the other hand, the concept of "Islamic", implying the transition from culture to religion, also turns out to be problematic when applied to Portugal. In fact we currently witness a timid academic institutionalization of Religious Studies encompassing, among others, Islamic religion. But the general panorama in Portugal lacks, today as in the past, any output related to the hermeneutics of Islam, sometimes reduced - even in the academic milieu - to a generic historical-cultural approach ${ }^{4}$. The title of this article was chosen in the light of this double perspective, which criticizes the very notion of "Arabic-Islamic Studies" as far as the Portuguese reality is concerned. In fact, the output that is intended to analyse has to do with Muslims, essentially. This is more in line with the intellectual output in fields such as History, Anthropology and Heritage proposals regardless of the presence or absence of the Arabic language, either in the object of study or in those who observe it ${ }^{5}$.

\section{Portugal and Spain: diverging paths}

In this sense, comparing Portuguese reality to the Spanish one, represented in this journal by Manuela Marín, will underline the differences that exist in relationships and models. The title itself - "Reflexiones sobre el arabismo español: tradiciones, renovaciones y secuestros" - points toward a well-defined field of study, going back to a "school" of Spanish Arabists founded by Francisco Codera (1836-1917) and crowned by Emilio García Gómez

\footnotetext{
${ }^{2}$ Maria Cardeira da Silva, "O sentido dos árabes no nosso sentido. Dos estudos sobre árabes e sobre muçulmanos em Portugal”, Análise Social, 39 (173), 2005, p. 781,

${ }^{3}$ In fact, the earliest stage of Arabic studies in Protestant Europe, in the $16^{\text {th }}$ and $17^{\text {th }}$ centuries, was driven by the argument that knowledge of Arabic was a tool for better understanding the etymology of Hebrew, and hence Biblical exegesis - Eva-Maria von Kemnitz, Portugal e o Magrebe (séculos XVIII/XIX). Pragmatismo, inovação e conhecimento nas relações diplomáticas, s.l., Ministério dos Negócios Estrangeiros, 2010 (Coleção Biblioteca Diplomática do MNE - Série D), p. 338.

${ }^{4}$ AbdoolKarim Vakil, "Pensar o Islão...", pp. 31-32.

${ }^{5}$ The article by anthropologist Maria Cardeira da Silva, titled "O sentido dos árabes no nosso sentido. Dos estudos sobre árabes e sobre muçulmanos em Portugal" also underscores this emphasis on the object of study. On the dichotomy between "Arabs" and "Muslims", which the author does not explain, it seems to turn out, however, that the former are defined as a function of an Arabic-speaking cultural context (both in the present and in Al-Andalus times), while the term "Muslims" applies to a situation of minority (Maria Cardeira da Silva, "O sentido dos árabes...", p. 788). Nevertheless, since not all Muslims are Arabs, or even speak Arabic, neither is every Arab a Muslim, the term "Muslim" is used in this text when referring to individuals or groups of Islamic religion.
} 
(1905-1995). Notwithstanding the author's critical analysis on the reproduction of a "canonical perspective", Arabism in Portugal, as already mentioned, will never become consolidated.

Its origins can be traced back to the $18^{\text {th }}$ century, in the context of an already late Orientalism. The ideas proposed by Fr. Manuel do Cenáculo (1724-1814) to reform the plan of studies within his congregation, the Ordem Terceira da Penitência, adopted in the context of Pombal's reforms, will lead to the introduction of Greek, Hebrew, Syriac and Arabic classes. In 1768, in the Monastery of Our Lady of Jesus (Convento de Nossa Senhora de Jesus), in Lisbon, the teaching of Arabic begins, making use of the temporary presence of Maronites in Portugal $^{6}$. One of these, Paulo Hodar, was actually made teacher of Oriental Languages in Coimbra University, holding the position from January $2^{\text {nd }}$ to his death, in 1780 . He only taught Hebrew, however, as he never had any students of Arabic ${ }^{7}$.

In 1772, Fr. António Baptista Abrantes is made the first teacher of the Arabic Language chair, giving his lessons in the convent mentioned before. A new phase thus begins, no longer dependent on foreigners present in the kingdom to guarantee teaching; in theory at least, the reproduction of knowledge was now guaranteed by the Portuguese, as well as the hope of continuity in such teachings ${ }^{8}$. The development of this process, however, is not linear. The political conditions brought about by the death of king D. José and the rise to the throne of queen Maria I will cause the suspension of Pombal's reforms, including those that affected Oriental languages. It is in this context, that Fr. Manuel do Cenáculo will be sent away from Lisbon, taking up in 1777 the diocese of Beja, which he had been granted in 1770. So he witnesses the end of Arabic language teaching in his convent, precisely on the year he leaves Lisbon, and also, by a royal decree of 1780 , he sees the abolishment of its study plan. After a brief suppression, teaching is resumed in a semi-official capacity, owing possibly to the important figure of Fr. João de Sousa, who on April $12^{\text {th, }} 1795$ is granted the title of Professor Proprietário of Arabic. The public character of these studies is thus regained. It fell to his disciples to ensure teaching after his death in 1812, until the extinction of religious orders in $1834^{9}$.

This "school of friars", for that is what it was, spans two generations. Fr. João de Sousa, coordinator of the Arabic chair (1794-1812) with the help of its first substitute teacher, Fr. José de Santa Moura, was followed by his disciple Fr. Manuel Rebelo da Silva who, in 1813, took up the chair of Arabic Language in the same Monastery of Our Lady of Jesus. In 1816, in turn, his disciple Fr. António de Castro was made the last substitute teacher. The extinction of the religious orders left these men without pay until October $20^{\text {th }} 1834$, when a decree solved this problem by making them equivalent to teachers of the public instruction system. Fr. Manuel went on performing services in Morocco and giving Arabic lessons in private. In 1844 there was a second restructuring of the Arabic chair. This made Fr. Rebelo da Silva once again an official teacher, helped by Fr. António de Castro, who replaced him from 1845 to his own death, sometime before $1849^{10}$.

After this, comes an almost total void. In fact, this "school of friars" produced yet another teacher, António Caetano Pereira, trained by Fr. Rebelo da Silva who, in a temporary capacity, coordinated the chair from 1852 to 1858 . But December 1860 saw the appointment of Augusto Suromenho, trained by Pascual de Gayangos in Madrid, as permanent professor of Arabic ${ }^{11}$. The Portuguese "school" had been reduced to a particular character that in fact has come down to the present day.

\footnotetext{
${ }^{6}$ Eva-Maria von Kemnitz, Portugal e o Magrebe..., pp 138-139; 154-159.

${ }^{7}$ Eva-Maria von Kemnitz, Portugal e o Magrebe..., p. 157.

${ }^{8}$ Eva-Maria von Kemnitz, Portugal e o Magrebe...,p. 333.

9 Idem

${ }^{10}$ Eva-Maria von Kemnitz, Portugal e o Magrebe...,pp. 363-378.

${ }^{11}$ Eva-Maria von Kemnitz, Portugal e o Magrebe...,pp. 503-504.
} 
Only with the advent of the First Republic, when in 1914 David Lopes (1817-1942) took up the chair of Arabic at the University of Lisbon, did all this knowledge finally gain entrance into academia. David Lopes received his training in Paris (after graduating in Literature in Lisbon) at the École Nationale des Langues Orientales Vivantes and the École Pratique des Hautes Études, marking the beginnings of what is considered to be the $20^{\text {th }}$ century's first school of Arabists ${ }^{12}$. His disciples include Joaquim Figanier (1869-1962), who studied for two years at the Institute des Hautes Etudes Marocaines in Rabat, and took up the chair of Arabic Language and Literature in the Faculty of Arts from the Lisbon University ${ }^{13}$, and then, in 1946, moved on to the Institute of African and Oriental Languages, at the Colonial Superior School, to which the discipline had been transferred ${ }^{14}$. After an interruption, his disciple Pedro Cunha Serra (1909-2002) took up the same chair, in the said institution, in 1965. Previously, he had studied Arab Philosophy at the Faculty of Philosophy and Arts in Madrid, from 1957 to 1961, where he defended his Ph.D. thesis (Contribuición topo-antroponímica para el estúdio del noroeste peninsular $)^{15}$. Likewise, José Domingos Garcia Domingues (1910-1989), a disciple of David Lopes and Figanier ${ }^{16}$, (trained, like the others, at the Faculty of Arts in Lisbon) who from 1983 to 1988 taught at University of Algarve, studied Arabic philology at the University of Madrid as well. At Coimbra's University it is Manuel Augusto Rodrigues who, from 1963 on, teaches, among other chairs, History of Religions and Arabic and Hebrew Languages and Cultures. His path sets him apart from the others: he graduated in Theology and Biblical Sciences and in Semitic Languages, at Rome's Pontifical Gregorian University and the Pontifical Biblical Institute respectively, from 1955 to 1962. In addition, he attended the École Biblique et d'Archéologie Française in Jerusalem (1962-1963) ${ }^{17}$.

These descriptive elements, in a text which aims to be critical rather than exhaustive ${ }^{18}$, serve as good illustration of the point mentioned before - the absence of a school of Arabism in Portugal, as opposed to the situation in Spain and, for that matter, in other European countries. Even after David Lopes, the training of university teachers of Arabic fails to guarantee internal self-sufficiency for reproduction. It is necessary to resort to foreign places, especially Madrid in this case, for supplementary training. This shows a strong contrast between two perspectives: in Portugal, the Arabic language still had, in the $20^{\text {th }}$ century, a merely complementary dimension which had to do, in the first phase of Arabism, with diplomatic contacts with Morocco ${ }^{19}$, and in the second, with the colonial statute.

\footnotetext{
${ }^{12}$ See for example Fernando Branco Correia, "Al-Andalus en la Historiografía Portuguesa (del siglo XIX a inicios del XXI). Un breve intento de sistematización", in Al-Andalus, España: Historiografias en Contraste, ed. Manuela Marín, Madrid, Casa de Velásquez, 2009, p. 167.

13 http://memoria.ul.pt/index.php/Figanier, Joaquim Fernando de Abreu (consulted on December $15^{\text {th }} 2013$ )

${ }^{14}$ See, on these data: Eva-Maria von Kemnitz, "The Centenary of the Republic and the Republic of Letters: Arabic Studies in Portugal 1910-2010", in Sirat al-Ğāhiz. Roccznik Orientalistyczny 64-1 (2011), ed. Marek M. Dziekan, Paulina B. Lewicka, Katarzyna Pachnia, Warszawa, Elipsa, 2011, pp. 121-132; Adel Sidarus, "Os estudos árabes em Portugal (1772-1962)”, in Islão e Arabismo na Península Ibérica, ed. Adel Sidarus, Évora, Universidade de Évora, 1986, pp. 37-54 (Portuguese version), pp. 55-73 (English version); A. Dias Farinha, "Os estudos árabes na historiografia posterior a Herculano", in A Historiografia Portuguesa de Herculano a 1950, Lisboa, Academia Portuguesa de História, 1978, pp. 203-304.

${ }^{15}$ [s.a..], Catálogo do Legado Bibliográfico de Pedro Cunha Serra, Lisboa, Academia das Ciências, 2006, p. 3.

${ }^{16}$ Fernando Branco Correia, “Al-Andalus en la Historiografía Portuguesa...", p. 168.

${ }^{17}$ http://www.wook.pt/authors/detail/id/45626 (consulted on December $15^{\text {th }} 2013$ ).

18 Consequently, this leaves out a whole group of teachers of Arabic who currently carry out their work in Portuguese universities.

${ }^{19}$ From the last quarter of the $18^{\text {th }}$ century the diplomatic relations with North Africa motivated the interest in the Arabic language, due to the necessity of an official documentation in Arab and the convenience to dispense foreign interpreters. In the second quarter of the $19^{\text {th }}$ century the focus on the
} 
This complementary dimension also affects the background training of these teachers, carried out in other scientific areas: Joaquim Figanier in Romance Philology, Pedro Cunha Serra in Classical Philology ${ }^{20}$ and José Domingos Garcia Domingues in Historic and Philosophical Sciences. The generation that followed, with António Dias Farinha, first at Universidade Nova de Lisboa and later at the Faculty of Arts from the Lisbon University (from which he retired in 2010) and Adel Y. Sidarus, at the University of Évora, from 1997 to 2008 (already retired as well), reflects again the reality of foreign-based training, although with different nuances. The former, who graduated in History at Lisbon University, received a degree in Arabic at the École Nationale des Langues Orientales Vivantes, in Paris ${ }^{21}$; the latter, of Egyptian origin, completed his doctorate in Oriental Studies at Munich University. The case of this docent illustrates another trend, that of resorting to native speakers of Arabic. Although limited to Adel Y. Sidarus at the time he was teaching, it has been spreading in Portuguese universities and currently dominates the scene, owing much to people's mobility at the turn from the $20^{\text {th }}$ to the $21^{\text {st }}$ century ${ }^{22}$.

So this fragmentation of teaching (not to mention other languages connected to the Islamic world, such as Turkish, Persian or the Berber dialects ${ }^{23}$ ), never developed into a continuous perspective, structured in a course of Arabic philology. The same is true of Hebrew, by the way. The consequences are felt in different domains, aside from that of language itself. Lacking such a foundational nucleus, instruments such as those developed in Spain in the last quarter of the $20^{\text {th }}$ century with the fundamental work by F. Corriente (A Grammatical Sketch of the Spanish Arabic Dialect Bundle, Madrid, 1977), never existed in Portugal. In fact, Fr. João de Sousa published, in 1795, a Compendio da Gramática Arábica, Abreviado, Claro e Mais fácil para a inteligência e ensino da mesma língua, coligido dos melhores gramáticos (Compendium of Arabic Grammar, Short, Clear and Easier for the intelligence and education of the same language, collected in the best grammarians) (Lisboa, Academia Real das Ciências) ${ }^{24}$. Two centuries would go by until a new initiative in Portuguese appeared, although limited to a basic and general introduction to the language - Mostafa Zekri and Jorge Baptista's Manual de Iniciação ao Árabe (Guide of initiation to Arabic) (Faro, FCHS-Universidade do Algarve, 2002), a teaching tool used by the former as a teacher of Arabic at University of Algarve.

In this way, the network of scholars of the field (to use Maria Cardeira da Silva's term) neither possesses nor generates its own scientific instruments. This leads to an inevitable loss of terminological consensus, affecting also the rules of transcription and Portuguese Islamic

Sub-Saharan Africa lead to the extinction of the Arabic studies, no longer necessary to the Portuguese diplomacy - Eva-Maria von Kemnitz, Portugal e o Magrebe...,pp. 325-326

${ }^{20}$ http://memoria.ul.pt/index.php/Serra, Pedro Maria da Rocha Cunha (consulted on December $22^{\text {nd }}$ 2013).

${ }^{21}$ His academic trajectory also includes a degree in Medicine, with a later Ph.D. and agregação in History.

http://www.eracareers.pt/opportunities/index.aspx?task=showMember\&jobID=10853\&jurilD=6206\&la ng=en\&idc=3 (consulted on December $22^{\text {nd }} 2013$ ).

${ }^{22}$ Some docents lie outside this perspective: António Lázaro, from Universidade do Minho, a disciple of António Dias Farinha, Fernando Branco Correia, from Universidade de Évora, who studied under Pedro Cunha Serra, and Eva Maria von Kemnitz, whose works have been widely used in this text, currently the director of the Master's Degree Program in Oriental Studies and of the Instituto de Estudos Orientais da Universidade Católica Her doctoral dissertation, "O Orientalismo em Portugal no contexto europeu e no das relações luso-magrebinas (sécs. XVIII e XIX), was oriented by A. Sidarus. She obtained her master's degree in 1976, in Oriental Philology (Arab and Islamic Studies), at the University of Warsaw, with the dissertation "Tradycje kultury arabsko-muzulmanskiej w Portugalii" (Tradições da Cultura ÁrabeMuçulmana em Portugal) - http://cecc.fch.lisboa.ucp.pt/investigadores/eva-maria-von-kemnitz.html (consulted on December 14th, 2013).

${ }^{23}$ Turkish and Persian are currently taught at The Faculty of Arts of the Lisbon University.

${ }^{24}$ Cf. Eva-Maria von Kemnitz, Portugal e o Magrebe..., p. 442. 
vocabulary ${ }^{25}$. The cohesion we would hope to see among these researchers, within a multidisciplinary perspective which would entail common reflection and conceptualisation, is absent from academia, although attempts at convergence do arise sporadically ${ }^{26}$. The consequences affect more than just the academic field. The work, which cannot be overlooked, by journalist Margarida Santos Lopes - Dicionário do Is/ão (Lisboa, Editorial Notícias, 2002), later complemented by Novo Dicionário do Islão (Lisboa, Casa das Letras, 2010) - inevitably suffers from this lack of common scientific instruments and terminology, added to defective knowledge of the language.

Another aspect sets apart the Portuguese and Spanish realities, concerning in this case the objects of study. Let us recall the "canonical narrative", mentioned by Manuela Marín, meaning the primeval "school" of Spanish Arabists, founded on the paradigm of the Hispanisation of the Al-Andalus. That discourse, ideologically driven to interpret the history of Spain and exclusively conditioned by it, generated important repercussions later on, when in the 1950's the discussion of Spanish national identity made Américo de Castro and Sanchéz Albornoz confront each other. Muslims, or Jews for that matter, never became in Portugal the subjects of an identity discourse such as the one found in the first of those authors ${ }^{27}$. On the other hand, it must be said, neither did they have to endure the more recent abduction ("secuestro", in the words of M. Marín) embodied in the works of Serafín Franjul, which made a very expressive impact in Spanish society by spreading the idea of a "pure" Spanish identity $^{28}$, expurgated from any Muslim, Jewish or even Gypsy influence ${ }^{29}$.

Such abductions in Portugal, until the 1974 Revolution, played a different role in official historiography, almost exclusively connoted with the triumphant Christian "Reconquista" and, above all, with Portuguese expansionism. Due to insufficient knowledge of the language, translations from Arabic (always present in Spanish output) were practically nonexistent in Portugal, then as now. An absolute comparison cannot be attempted in this field: in

\footnotetext{
${ }^{25}$ See criticism, in the same direction, by AbdoolKarim Vakil, "Pensar o Islão...", p. 32. An example of this terminological dispersion and lack of definition can be seen in the mentioned article, by Maria Cardeira da Silva, and in the distinction drawn by the author between Arabs and Muslims (see Note 5).

${ }^{26}$ See the thematic issue of the journal Análise Social, vol. XXXIX (173) from 2005 where, under the heading "Europe and Islam", a majority of anthropologists is joined by some sociologists and an archaeologist. The post-graduate studies program "Islão Contemporâneo. Culturas e Sociedades" "Contemporary Islam, Cultures and Societies" (organized by the Department of Anthropology from the Faculty of Social and Human Sciences, Universidade Nova de Lisboa - FCHS-UNL-, the Núcleo de Estudos em Contextos Islâmicos - NECl - (Center for Studies in Islamic Contexts) and the Language Institut from the same University-ILNOVA- and coordinated by Maria Cardeira da Silva) implies a stronger participation by historians, as well as the offering of two levels of Arabic and Turkish. However this course, launched in the 2012-2013 and 2013-2014 school years, did not collect the number of candidates required for opening.

${ }^{27}$ See Maria Filomena Lopes de Barros, "Ethno-Religious Minorities", in The Historiography of Medieval Portugal (c.1950-2010) dir. José Mattoso, ed. Maria de Lurdes Rosa, Bernardo Vasconcelos e Sousa, Maria João Branco, Lisboa, Instituto de Estudos Medievais, 2011, pp. 571-573.

${ }^{28}$ See text by Manuela Marín.

${ }^{29}$ In a text published in 2002, corresponding to a conference given by the author at the VIII Simposio Internacional de Mudejarismo, in September 1999, under the title "Gitanos y Moriscos: verdade y ficción", Serafín Franjul already defended his theory (widely developed later in his successful works, AlAndalus contra España and La quimera de al-Andalus, several times published and reprinted), arguing that belonging to a group required "not only one's birth in a specific place - as $A$. Castro naively intended when he said that the Mudéjares were Spaniards" but also that place's cultural connotations, participation in its objectives "and, naturally, the express will of that inscription" which the minorities lacked. His perspective on those minority groups is summed up in a definitive sentence: "from Spain, they only wanted the use of her territory" - Serafín Franjul, Gitanos y Moriscos: verdad y ficción”, in VIII Simposio Internacional de Mudejarismo. Actas, vol. I, Teruel, 2002, p. 15.
} 
the library of El Escorial alone, around 2500 Arabic manuscripts are kept $^{30}$. In Portuguese archives and libraries it is impossible to advance figures, since an exhaustive inventory is lacking, despite the contribution made in this respect by Sidarus ${ }^{31}$. Its numbers do not come even close to those of Spain, however, to judge from surveys already made. This does not mean that translation would not have been one of the Arabists' goals, had a school been put together - which it wasn't. Translations can be listed summarily: those made under the "school of friars", with Fr. João de Sousa and his disciple Fr. Vicente Salgado ${ }^{32}$, and the incomplete translations by David Lopes, concerning some aspects of the Gharb al-Andalus (published in Os árabes nas obras de Alexandre Herculano) which were cut short by the author's death ${ }^{33}$.

We owe David Lopes, in fact, the inclusion of a chapter on the "Arab dominion" in the greatest piece of historiographical output from the 1920's, the História de Portugal directed by Damião Peres, also known as the História de Barcelos. Although lacking in innovation, he makes use of the scientific output of his day, producing a synthesis of that dominion's main periods which all but ignores the specificities of what would later become the Portuguese territory ${ }^{34}$. It is on the Portuguese expansion in Morocco, nevertheless, that he leaves his more innovative historiographical mark, taking up a rather larger space in the work mentioned. This is the field into which David Lopes invested a significant part of his scientific efforts. In 1897, he published Os textos em aljamia portuguesa, containing copies of letters (with one exception only) from the Torre do Tombo archive, addressed by North-African barons to the Portuguese king and written in Portuguese with Arabic characters ${ }^{35}$; in 1915 , he published Volume I of the Anais de Arzila $^{36}$, followed in 1919 by its second volume ${ }^{37}$; from 1924 to 1925, the História de Arzila $^{38}$; in 1937 he collaborated in the História da Expansão Portuguesa no Mundo, more precisely in its first part, called "A expansão em Marrocos" ${ }^{13}$; and finally he became cocoordinator, alongside Robert Ricard, of the monumental Sources Inédites de l'Histoire du Maroc.

30 http://rbme.patrimonionacional.es/home/Sobre-la-Biblioteca/Composicion-del-fondo-bibliograficomanuscrito/Manuscritos-arabes.aspx (consulted on December $15^{\text {th }}$ 2013).

${ }^{31}$ See for example, by this author: "Manuscrits arabes du Portugal", in La signification du Bas Moyen Age dans l'histoire et la culture du monde musulman: actes du $8^{e}$ Congrès de l'Union Européenne des Arabisants et Islamisants, Aix-la-Provence, 1976, pp. 283-288; "Manuscritos árabes em Portugal", Estudos Orientais 2: O legado cultural de judeus e mouros (1991), pp. 117-126. He also took part in drawing up the inventory of the Academia das Ciências (see A. Sidarus "Notas sobre a descrição dos manuscritos árabes", pp. XII-XIII), included in the Catálogo de Manuscritos, Série Vermelha, I ( $\mathrm{N}^{\text {os. }} 1$ to 499), preface by Joaquim Veríssimo Serrão, Lisboa, Academia das Ciências, 1978. In May 2009, Maria Jesús Viguera carried out, in Portugal, an investigation into "Manuscritos y documentos árabes en Portugal".

${ }^{32}$ About these productions: Eva-Maria von Kemnitz, Portugal e o Magrebe...,pp. 440-480.

33 "Os árabes nas obras de Alexandre Herculano. Notas marginais de língua e história portuguesa", Boletim da Segunda Classe da Academia das Ciências de Lisboa, no 3 (1910-1911), pp. 50-84, 198-253 and 323-377 and no 4, pp. 321-402.

${ }^{34}$ In this sense he recovers, with innovations, the Romantic History of Alexandre Herculano and Oliveira Martins - see Fernando Branco Correia, "Al-Andalus en la Historiografía Portuguesa ...", pp. 163-166.

${ }^{35}$ Later republished: Os textos em Aljamia portuguesa. Estudo filológico e histórico, Lisboa: Imprensa Nacional, 1940.

${ }^{36}$ Anais de Arzila, crónica inédita do século XVI, por Bernardo Rodrigues, Tomo I (1508-1525), Coimbra, Imprensa da Universidade, 1915.

37 Anais de Arzila, crónica inédita do século XVI, por Bernardo Rodrigues, Tomo II (1525-1535) suplemento (1536-1550, Coimbra: Imprensa da Universidade, 1919.

${ }^{38}$ História de Arzila durante o Domínio Português, 2 vols. (1471-1550 e 1577-1589), Coimbra, Imprensa da Universidade, 1924-1925.

${ }^{39}$ História da Expansão Portuguesa no Mundo, dir. de Dr. António Baião, Hernâni Cidade e Manuel Múrias, Lisboa, Editorial Ática. Lisboa. 1937-1940. 
Aside from other dimensions of his work ${ }^{40}$, be it in philology ${ }^{41}$ or in publishing sources for other areas of the Portuguese expansion ${ }^{42}$, this tendency represents a substantial difference when compared to what was going on in Spain in the same period. There, the "Hispano-Arab" past, which would gradually be transmuted into the Al-Andalus, created - as proven by Manuela Marín's text - a centrality which cannot be found in Portugal. The asymmetry between this fact and the expansionist theme, inscribed in Portuguese colonial discourse up to 1974, does in fact push the Arab-Islamic dominion into an ever more marginal context in Portuguese historiography. Efforts by several authors, scattered throughout a multitude of articles, can only achieve very little visibility in the dominant historiographical discourse ${ }^{43}$.

\section{The rediscovery of Muslims}

The structural differences between the Portuguese and Spanish trajectories, based on the issues of language, translation and even the objects of discourse, underwent a transformation, in this last aspect, after the 1974 Revolution - sharing the general movement of Portuguese historiography as a whole. This transformation was kicked off by a work which reintroduced the issue of the Arab-Islamic dominion, this time linked directly to the territory of what later became the kingdom of Portugal. Published between 1972 and 1975 (Lisboa, Editorial Presença), the four volumes of Portugal na Espanha Árabe, by António Borges Coelho, cover not only historical excerpts but also materials drawn from geographical, philosophical and literary texts concerned with the land and characters of the Gharb al-Andalus, drawing up an outlook which left an indelible stamp on post- 1974 generations.

This selection of sources, translated from European languages and from works published mainly in Spain, constituted a strong call of alert to the silence that had lasted too long on the realities of the Al-Andalus, at the same time becoming an important tool for use in this field. The work was republished several times, but in the end came to bear no additional results. Its most recent edition, in 2008 (Lisboa, Caminho), exactly reproducing its original format, serves as proof of the scientific community's inability to renew the proposals that opened up new paths of research. Neither the progress made in publishing translated sources outside the country, nor the perspective of translating Arabic originals published in the meantime, made it possible to join forces in order to complement the work of this multifaceted author, always keen to engage in new historical and historiographical projects.

It is Archaeology, however, that brings about the decisive paradigm change regarding the Gharb al-Andalus, through the works which, starting in the late 1970's, will eventually originate the Mértola Archaeological Site. A different discourse takes hold: that of Mediterranean continuity, in the wake of geographer Orlando Ribeiro, a discourse which comes to encompass Arab-Islamic culture through the voice of its founder Cláudio Torres and that of his closest followers, Santiago Macias and Susana Gómez. Archaeology in fact proved to be, in this respect, "the most efficient field for the sustainability of identities" ${ }^{4}$, projecting a visibility which, from the media standpoint, became a real "gatekeeping concept", as stated by

\footnotetext{
${ }^{40}$ See on this subject A. Sidarus, "Os estudos árabes em Portugal"...

${ }^{41}$ As is the case with the text already mentioned: "Os árabes nas obras de Alexandre Herculano..." as well as others, namely "Toponímia árabe de Portugal", Revista Lusitana, 24, 1922, pp. 257-273, or still, "Cousas luso-marroquinas. Notas filológicas sobre particularidades vocabulares do português nas praças de África", Boletim de Filologia, 7, 1942, pp. 245-259..

${ }^{42}$ Such as Extractos da Conquista de Yaman pelos Otomanos, 1892 or the História dos Portugueses no Malabar, 1898.

${ }^{43}$ See, on this subject, the analysis of Joaquim Figanier's output: José Pedro Machado, Pedro Cunha Serra, José Domingos Garcia Domingues and Martim Velho in Fernando Branco Correia, "Al-Andalus en la Historiografía Portuguesa ...", pp. 167-170.

${ }^{44}$ Maria Cardeira da Silva, "O sentido dos árabes no nosso sentido....", p. 792.
} 
Maria Cardeira da Silva in 2005: "Mértola is evoked when one mentions Arabs, Muslims, immigrants, heritage, the past, art, poetry or Archaeology, being used as a pivotal axis in dossiers on themes related to war, the veil or terrorism" ${ }^{45}$.

This effect has been weakening with time, losing the markedly essentialist character it had some years ago, but the Mértola Archaeological Site did nonetheless introduce the AlAndalus and Arab-Islamic history to a wider audience, reinterpreting them and decisively projecting them into Portuguese historical discourse. The text by Cláudio Torres "O Gharb AlAndaluz", in the História de Portugal directed by José Mattoso, published in 1992, initiates the definitive inscription of the subject in all subsequent works of the same nature. Likewise, the visibility gained by Archaeology generated an investment at the Heritage and museology levels, contributing to a local development model which other urban centres aim to replicate. Somehow, Cláudio Torres seems to have "institutionalised" a field of study which, although previously in existence, had to wait for his work to obtain national and international projection, a fact officially acknowledged when he was awarded, in 1991, the Prémio Pessoa (Pessoa Prize).

Another publication (and another lifetime work as well) deserves to be mentioned here, owing to the consequences it had on Portuguese society - and once again by its impact on the media. Albeit on a parallel course since, unlike Cláudio Torres ${ }^{46}$, he was never accepted by academia, the lawyer Adalberto Alves published in 1998 his book O meu coração é árabe ("My heart is Arab"), with texts by Gharb Al-Andalus poets, poems by authors of what later became Portuguese territory and an introduction to Arab poetry. Although the translations, once again, were made from European languages, the book complemented and amplified the poetic proposals inserted by Borges Coelho in his Portugal na Espanha Árabe. Success was immediate, with Portuguese society, unaware of foreign bibliography on this subject, discovering Arab Islamic poetry - or more precisely luso-árabe, as the author states. Such success has stayed with Adalberto Alves in his multiple and varied output on the Portuguese Islamic past (over 30 books published), ranging from biographies to historical and esoteric essays or even translations from contemporary Arab poetry ${ }^{47}$. This continued labour of divulgation was acknowledged by the Sharjah International Prize, awarded to him by Unesco in 2008. His work, pursued outside academia, was crowned in 2013 with the publication of his Dicionário de Arabismos de Língua Portuguesa (Lisboa, Imprensa Nacional), with the support of Instituto Camões and UNESCO.

These two parallel paths have strongly marked distinct trends in the approach to Portugal's Arab-Islamic past. Recovering and absorbing previous output in their diverse fields of study ${ }^{48}$, both have projected Arab-Islamic issues onto the media centre-stage, moving beyond the Al-Andalus itself. The consequences surpassed their authors. Naturally, responses were diversified, generating multiple blogs, associations and even publications, which are meant to be of value in divulgation but sometimes fail to rise above the risible ${ }^{49}$. The Islam "fashion", strengthened of course by world events and the growing visibility of immigration

\footnotetext{
${ }^{45}$ Maria Cardeira da Silva, "O sentido dos árabes no nosso sentido....", p. 800.

${ }^{46}$ Having taught at Faculdade de Letras da Universidade de Lisboa after the $25^{\text {th }}$ April Revolution.

${ }^{47}$ See information (lacking updates) on this author in http://pt.wikipedia.org/wiki/Jos\%C3\%A9 Adalberto Coelho Alves (consulted on December $15^{\text {th }}$ 2013) 48 José Luís de Matos, an archaeologist and former professor at the Faculty of Arts from the Lisbon University defended, in the tribute Homenagem a Cláudio Torres, held in that institution on April $19^{\text {th }}$ 2013, that he had been the "John the Baptist" of that researcher. In fact, he was the pioneer of ArabIslamic archaeology in Portugal, standing alongside Cláudio Torres and Borges Coelho as one of the founders of the Mértola Archaeological Site.

${ }^{49}$ See for example the critical review by Stéphanne Boisselier to the book $O$ espaço ibero-magrebino durante a presence árabe em Portugal e Espanha (Coimbra, Palimage, 2012), in Lusitana Sacra, 27 (Janeiro-Junho 2013), pp. 211-213.
} 
from Muslim countries ${ }^{50}$, is still based on a superficial and distorted essentialism, stemming from a multicultural Al-Andalus discourse, just like in Spain as well ${ }^{51}$. It is a "paradise lost" of tolerance and, very often, of Esoterism, radically opposed to the colonial mentality dominant before the 1974 Revolution, expressing one aspect, among many, of the country's democratic transformation. Just like its Arabophilia counterpart, however, it suffers from lack of criticism and scientific reflection, which do little to help bring about changes in society or in the scientific paradigm itself.

In this perspective, how do the Social and Human Sciences respond to these societal challenges? Academia still reveals, as mentioned above, serious failings in the analysis of the Arab-Muslim past, not least the deficient knowledge of the language. Also, the dispersion of the researchers' network hinders any concerted effort to put together a glossary or other common work tools (as referred before), which may be of use not only to the scientific community but also to Portuguese society as a whole. The Dicionário do Is/ão, written by a journalist, and the Dicionário de Arabismos, by Adalberto Alves, show very clearly what academia does not do... but definitely should.

However, some aspects did see exponential development, especially from the 1990's onwards. In the wake of the Mértola site, Arab-Islamic Archaeology, which was practically nonexistent, managed to put together a network of Archaeologists spread throughout the country and inside the universities ${ }^{52}$. Their work, unfolding in multiple excavations and publications ${ }^{53}$, is in fact one of the most important for generating an effective transformation in historical discourse. Such a network also promotes regional and local identitarian affirmation, when archaeological remains are treated as museum items and become part of tourist routes ${ }^{54}$. This economical sustainability is not put into practice as visibly in other scientific areas. A new tendency, however, may be created by this discourse: that of patrimóniotopia, i.e., "heritage

\footnotetext{
${ }^{50}$ The settlement, from 1974 on, of a Muslim community originated in the former Portuguese colonies which later became the Islamic Community of Lisbon, - also strengthened this tendency, including the efforts by its former president Suleiman Valy Mamede, who was able to raise the funds needed for building the mosque.

${ }^{51}$ On the other hand, this reality does not attain the same levels of identitarian assertion as is the case in Andaluzia, for examle.

${ }^{52}$ This is well exemplified by the prize in Archaeology given by Fundação Gulbenkian to Helena Catarino, professor at the Faculdade de Letras da Universidade de Coimbra, for her Ph.D. thesis O Algarve Oriental durante a Ocupação Islâmica: Povoamento Rural e Recintos Fortificados (3 vols, Al'Ulya, no 6, Loulé, Arquivo Histórico Municipal de Loulé, 1997-1998).

${ }^{53}$ See on this subject: "Actas do 6o Encontro de Arqueologia do Algarve. O Gharb no al-Andalus: síntesis e perspectivas de estudo. Homenagem a José Luís de Matos (Silves 23, 24 e 25 de Outubro 2008, Xelb 8 (2009); Isabel Cristina Ferreira Fernandes and Santiago Macias «Islamic and Christian Medieval Archeology" in The Historiography of Medieval Portugal (c.1950-2010) dir. by José Mattoso, ed. by Maria de Lurdes Rosa, Bernardo Vasconcelos e Sousa, Maria João Branco, Lisboa, Instituto de Estudos Medievais, 2011, pp. 153-178; Fernando Branco Correia, "Al-Andalus en la Historiografía Portuguesa...", pp. 178-179; Hermenegildo Fernandes, "The Gharb al-Andalus", in The Historiography of Medieval Portugal (c.1950-2010)..., pp. 557-558.

${ }^{54}$ See for example the initiative by the Museum without Frontiers, owing to Cláudio Torres and Santiago Macias, setting up the route "Terras da Moura Encantada: arte islâmica em Portugal" http://www.mwnftravels.net/travel et trailDetail.php?id=IAM;pt;1;pt\&fl=its (Cláudio Torres, Santiago Macias et alii, Terras da Moura Encantada: arte is/âmica em Portugal, Porto, Civilização, 1999) and, more recently, the "Rota al-Mutamid" in the Algarve - http://www.sulinformacao.pt/2013/04/herancaislamica-colocada-ao-servico-da-cultura-e-do-turismo-na-rota-al-mutamid/ (consulted on January 20th 2014).
} 
as an imaginary place" ${ }^{25}$, if a constant dialogue is not maintained between science and scientific divulgation.

Nevertheless, the "breakdown of barriers" between History and Archaeology, affecting the changes in our knowledge of the Gharb Al-Andalus, shows an asymmetry which very evidently favours the latter science. The most recent historic synthesis dates from 2000: Cristophe Picard's Le Portugal musulman (VIIle-XIIle siècles), (Paris, Maisonneuve et Larose), methodologically based on interpretation of Arab sources, but without overlooking material inputs $^{56}$. Another perspective, however, is currently taking shape: that of a medieval period shared by Latin-Christian and Arab-Islamic cultures which, based on the theoretical principles of a "frontier society", has been generating new interpretative propositions on the territory that was to become the Portuguese kingdom ${ }^{57}$. Along these lines a school of young historians is taking shape ${ }^{58}$, which only the future will be able to judge, but whose heuristic renewal necessarily implies greater requirements, namely that of solid linguistic training in both Arab and Latin.

The centrality of the Gharb Al-Andalus could not, of course, eclipse the broader history of Muslims in general. The 1990's also saw the beginnings of another historical narrative: that of the Portuguese kingdom's Muslim minority ${ }^{59}$, whose paradigm had become crystallised in the work of Leite de Vasconcelos (1858-1941), reviewed, systematised and enlarged by M. Viegas Guerreiro ${ }^{60}$. Another player from the same period was also introduced, namely the Morisco minority, totally absent from the historical canon until that time. In fact, it was the thesis by researcher Ahmed Boucharb, oriented by Bernard Vincent, which got things going in this field. Nevertheless, we owe the first general work on this subject to Isabel Drummond Braga, who in 1999 published her book Mouriscos e Cristãos no Portugal Quinhentista: duas culturas e duas conceções em choque, (Lisboa, Hugin), and who has carried on in her productive research on this subject ${ }^{61}$. Boucharb's thesis, titled Os pseudo-mouriscos de Portugal no séc. XVI, would see publication only in 2004 (Lisboa, Hugin), the same year that Rogério Ribas (d. 2012), from the Universidade Federal Fluminense (Brazil), defended his doctoral thesis at the Faculdade de Letras de Lisboa, under the title Filhos de Mafoma: Mouriscos, Cripto-Islamismo e Inquisição no Portugal Quinhentista ${ }^{62}$.

55 For this concept see: Paulo Simões Rodrigues, “Patrimóniotopia: o Património como Lugar Imaginário", in Arte e Utopia, coord. Margarida Acciauoli, Ana Duarte Rodrigues, Maria João Castro, Paula André e Paulo Simões Rodrigues, CHAIA- UÉ /DINÂMIA'CET-IUL/FCSH-UN, 101-110.

56 A more recent perspective is seen in the doctoral dissertation by Fernando Branco Correia, Fortificações Guerra e Poderes no Gharb al-Andalus (dos inícios da islamização ao domínio norteafricano), defended at the University of Évora in 2010, still to be published.

${ }^{57}$ Hermenegildo Fernandes, "The Gharb al-Andalus"..., pp. 578-579.

${ }^{58}$ Centred mainly on the Department of History from the University of Lisbon, around Hermenegildo Fernandes. This trend was strengthened by the creation of the Master's Degree Program "História do Mediterrâneo Islâmico e Medieval"( "History of the Islamic and Medieval Mediterranean") , involving the Universities of Lisbon, Évora and Algarve.

${ }^{59}$ See Jean-Pierre Molénat's article on the Mudéjares in this journal.

60 "Mouros" in Etnografia Portuguesa, vol. IV, Lisboa, Imprensa Nacional, 1982, pp. 299-350. On this issue see Maria Filomena Lopes de Barros, "Ethno-Religious Minorities", in The Historiography of Medieval Portugal (c.1950-2010) dir. by José Mattoso, ed. by Maria de Lurdes Rosa, Bernardo Vasconcelos e Sousa, Maria João Branco, Lisboa, Instituto de Estudos Medievais, 2011, pp. 571-573.

${ }^{61}$ See, for instance, from this author, "Relações Familiares e Parafamiliares dos Mouriscos Portugueses", Historia y Genealogia, [on line] 2 (2012), pp. 201-213; "Portugal e os Mouriscos de Espanha nos séculos XVI e XVII", in La política y los moriscos en la época de los Austria. Actas del Encuentro, Madrid, 1999, pp. $231-247$.

62 From the "Ocidentalization" of the Muslim and Morisco minorities to the Orientalism of Islam, another trend was developed in the History over the Portuguese expansion. After the 1974' Revolution, the Other, including the Muslim, became a focus of interest, overcoming, at least in certain circles, the 
Studies on the Muslim/Morisco minority, however, have failed to achieve the desired dimension, owing to the lack of a critical mass interested in doing research in this field. The difficulties felt by the Social Sciences in Portugal, until the 1980's/90's, "in identifying immediate phenomena not framed by established intellectual tradition"63 (to quote anthropologist Cristiana Bastos) still seem to influence historical discourse today. Contaminated by the prevailing mentality, this discourse has returned to a political history, however "new", which stresses the importance of the institutions, individual and the social elites. As José Alberto Tavim states in this journal, about the Jewish studies, "the hegemonic theoretical apparatus" in History still consecrates nowadays the "imposition of the norm and not the resistance". The past of Portugal's Muslims and for that matter of other ethnic groups, is, therefore, still to be accomplished.

Eurocentric discourse of the triumphant Portuguese Empire. Nevertheless, the specificity and complexity of this field were not within the scope of this text.

${ }^{63}$ Cristiana Bastos, presentation of Europa e Islão, Análise Social 173 (2005), p. 761. 